\title{
Addictions among Indian Elderly Population: A Matter of Concern
}

\author{
*Harshal Tukaram Pandve \\ Department of Community Medicine, Smt. Kashibai Navale Medical College, India
}

Submission: July 21, 2017; Published: July 25, 2017

*Corresponding author: Dr. Harshal Tukaram Pandve, Associate Professor, Department of Community Medicine, Smt. Kashibai Navale Medical College, Narhe, Pune, Maharashtra state, India, Email: dr_harshalpandve@yahoo.co.in

\section{Addictions Among Indian Elderly Population: A Matter Of Concern}

The world's older population continues to grow at an unprecedented rate. Today, 8.5 percent of people worldwide (617 million) are aged 65 and over. According to a new report, "An Aging World: 2015," this percentage is projected to jump to nearly 17 percent of the world's population by 2050 (1.6 billion) [1]. According to Population Census 2011 of India, there are nearly 104 million elderly persons (aged 60 years or above) in India; 53 million females and 51 million male. Percentage share of elderly persons in the population of India is ever increasing since 1961 . While in 1961, 5.6 per cent population was in the age bracket of 60 years or more, the proportion has increased to 8.6 per cent in 2011. The trend is same in rural as well as in the urban areas. In rural areas while the proportion of elderly persons has increased from 5.8 per cent to 8.8 per cent, in urban areas it has increased from 4.7 per cent to 8.1 per cent during 1961 to 2011 [2]. Available scientific literature has shown that addictions are not limited to a specific age group though more concern is given to addiction among youth and adult population. Addictions among elderly is one of neglected problems in many parts of the world including India. Due to insufficient knowledge, lack availability of related data, lack of infrastructure and facilities, addictions among elderly population in India remains underestimated, under identified, under diagnosed as well as undertreated similar to many other countries [3].

In India, review of research literature shows that very few studies have focused on addictions among elderly population. As per study conducted by Mundada et al. [4] (2013) among rural population of Aurangabad in Central Maharashtra, the prevalence of addiction among elderly males was $68.34 \%$, the prevalence of various addictions were smoking $29.96 \%$, alcohol $18.18 \%$, tobacco chewing $29.29 \%$ and among elderly females, $45.42 \%$ elderly females use to chew tobacco. $40.40 \%$ males and $50.60 \%$ females were having addictions like Hukka, Bhang, betel, and pan. Study found significantly higher proportion of males were having addiction of alcohol and smoking [4]. According to study carried out by Davey et al (2016) in North India, the prevalence of tobacco usage among elderly was $56.7 \%$, in which smoking was the dominant one (37\%) and majority being in the form of Bidi (56.7\%). Tobacco usage was significantly associated with age, sex, and caste, occupational and socio-economic status as well as literacy status [5]. As per study conducted by Goswami et al. [6] (2005), the prevalence of smoking was $71.8 \%$ in males and $41.4 \%$ in females. Regular alcohol intake was seen in $16.3 \%$ of the males compared with $0.8 \%$ of the females [6]. According to study carried out by Pandve and Deshmukh (2010) among elderly population in urban slum in Pune city tobacco chewing is bigger threat as not just males; females too were addicted to it. About 68\% males and 17\% females chewed tobacco. Alcohol consumption was seen in $42.1 \%$ of the males, none in females [7]. In the study conducted by Thakur et al. [8] (2013), revealed that $58.97 \%$ study subjects were using some or the other form of tobacco. Prevalence was 55.38\% more than half of the tobacco users were addicted to tobacco chewing in various forms. $2.7 \%$ of the study sample took alcohol [8]. In another study carried out by Pandve et al (2017) observed that 54\% elderly males had one or more addictions. $38 \%$ of the study subjects were addicted to Masheri which is a kind of chewing tobacco which is usually used for teeth cleaning. Most of the females were addicted to Masheri. 36\% of males were chewing tobacco with lime. 34\% of the males were smoking Bidi. 15\% males were alcoholic [9].

\section{Conclusion}

To conclude, addictions such as tobacco chewing, smoking and alcohol consumptions are common in elderly population of India. Such addictions further not only complicate the preexisting health problems but also are harmful to social and mental well being. It is need of the hour to address this neglected issue of the society.

\section{References}

1. World's older population grows dramatically.

2. Elderly in India (2016) pp. 1-104. 
3. Chapter 1 - Substance Abuse Among Older Adults: An Invisible Epidemic. Center for Substance Abuse Treatment. Rockville (MD): Substance Abuse and Mental Health Services Administration (US) 1998. Substance Abuse among Older Adults.

4. Mundada V, Jadhav V, Gaikwad AV (2013) Study of addiction problems and morbidity among geriatric population in rural area of Aurangabad district. Journal of Mid-Life Health 4(3): 172-175.

5. Davey S, Singh JV, Raghav SK, Muzammil K, Shankar R (2016) Tobacco use and its impact on pulmonary health among elderly population in rural area of Muzaffarnagar - A cross-sectional study. Indian J Tuberc 63(3): 183-191.
6. Goswami A, Reddaiah VP, Kapoor SK, Singh B, Dwivedi SN, et al. (2005) Tobacco and alcohol use in rural elderly Indian population. Indian J Psychiatry 47(4): 192-197.

7. Pandve HT, Deshmukh PR (2010) Health survey amongst the elderly population residing in an urban slum of Pune city, Maharashtra. Journal of Indian Academy of Geriatrics 6(1): 5-8

8. Thakur R, Banerjee A, Nikumb V (2013) Health problems among the elderly: a cross- sectional study. Ann Med Health Sci Res 3: 19-25.

9. Pandve HT, Chavan VM, Giri PA (2017) Study of health problems and addiction Pattern among elderly population in rural areas of Pune, India. Epidemiology (Sunnyvale) 7: 303.

\section{Your next submission with Juniper Publishers will reach you the below assets}

- Quality Editorial service

- Swift Peer Review

- Reprints availability

- E-prints Service

- Manuscript Podcast for convenient understanding

- Global attainment for your research

- Manuscript accessibility in different formats

( Pdf, E-pub, Full Text, Audio)

- Unceasing customer service

Track the below URL for one-step submission https://juniperpublishers.com/online-submission.php 